\section{Antibodies to intermediate filaments in polymyalgia rheumatica/giant cell arteritis: do they reflect the underlying disease activity rather than the acute phase response?}

The cytoplasm of eukaryotic cells contains a major filamentous system consisting of microfilaments (5-6 nm diameter, called 'actin filaments'), microtubules $(20-25 \mathrm{~nm}$ diameter) and intermediate filaments (7-11 $\mathrm{nm}$ diameter). ' Antibodies to intermediate filaments (AIF) are frequently found in the sera of patients with either viral or autoimmune diseases. The antibodies are usually of the IgM isotype. ${ }^{24}$ We have found AIF in polymyalgia rheumatica/giant cell arteritis (PMR/GCA)..$^{5}$ This inflammatory disease of the elderly is of unknown cause but certain features suggest an immune mediated disorder including the presence of anticardiolipin antibodies, ${ }^{6}$ increased levels of serum interleukin, ${ }^{67}$ an association with HLA-DR $4^{8}$ and decreased levels of CD8 $+\mathrm{T}$ cells in peripheral blood.

We have studied the prevalence of AIF in PMR/GCA to determine any possible relationship with disease activity and treatment. Twenty two patients with PMR/GCA were included in this study ( 15 women and 7 men, ranging in age from 52 to 87 years, mean age: $71 \cdot 18$ years). All fulfilled the diagnostic criteria of Jones and Hazleman. ${ }^{12}$ Each of them had four samples of serum taken at different stages of PMR/GCA: pretreatment (1), on treatment (2) and off treatment (1). Serum samples from 31 age and sex matched controls with non-inflammatory rheumatic conditions (back pain, neck pain, medial or lateral epicondylitis) were collected at Guy's Hospital. All sera were stored at $-20^{\circ} \mathrm{C}$. AIF were detected by indirect immunofluorescence on the Hep- 2 cell line as previously described. ${ }^{5}$ Only anti-vimentin antibodies are reported here. The observer was 'blind' to the clinical status of the sera being examined.

AIF were found in $52 \%$ of the 88 sera samples examined. However, 16 of 22 patients' sera $(72 \%)$ with active untreated PMR (figure) $v 9$ of $31 \quad(29 \%) \quad(\mathrm{p}<0.00001)$ of normal controls (figure) were positive. In those active untreated patients with PMR/ GCA, vimentin antibodies were found in 16 , prekeratin in 14 and a combination of both antibody specificities was found in 14 patients. These percentages decreased to $54 \%, 5.6$ months (range 3-7 months) after initiation of treatment and to $40 \%$ after 11.8 months (range 9-14 months) of treatment. By contrast, only $36 \%$ of patients had AIF positivity at 25.6 months from diagnosis (range 12-42 months) by which time all patients had ceased corticosteroid therapy. A chi-square analysis between pre-treatment and offtreatment PMR/GCA patients showed a highly significant difference $(p<0.00001)$.

Except for an association between AIF and arthralgia in patients with systemic lupus erythematosus,$^{10}$ no other clinical associations have been assigned to these antibodies and their value as diagnostic/prognostic markers has not been established in a specific disease. Since AIF are $\operatorname{IgM},{ }^{5}$ we proposed that AIF might disappear from the sera as PMR/GCA declines and eventually ceases; this has been supported by the results of this study. The AIF response appears to be the only well established autoantibody response in PMR. The disappearance of AIF only after the disease has 'burnt' itself out is reminiscent of other conditions such as viral diseases in which IgM antibodies to IF disappear with resolution of the disease. ${ }^{3}$ Thus AIF may be a better marker of underlying disease activity than the acute phase response.

In conclusion, we have found an increased incidence of AIF in active untreated PMR and that the incidence decreases more slowly than the acute phase response raising the possibility that measurement of AIF may be a convenient way of determining the underlying activity of PMR.

I MONTEAGUDO
V CORRIGALL
G S PANAYI
Rheumatology Unit, UMDS,
G POUNTAIN
B L HAZLEMAN
Guy's Hospital, London, United Kingdom
Rheumatology Research Unit,
Addenbrook's Hospital, Cambridge, United Kingdom
Dr Indalecio Monteagudo is a recipient of grant
93 is046 of Fondo de Investigaciones Sanitarias,
Ministerio de Sanidad y Consumo, Spain. Part of
this study was funded by grant P57 from the
Arthritis and Rheumatism Council of Great
Britain.

1 Bloemendal $\mathrm{H}$, Pieper $\mathrm{F} \mathrm{R}$. Intermediate filaments: known structure, unknown function. Biochem Byophys Acta 1989; 1007 $245-53$

2 Toh B H, Yildiz A, Sotelo J, et al. Viral infections and IgM antibodies to cytoplasmic intermediate filaments. Clin Exp Immunol 1979; 37: 76-82

3 Kurki P, Helve T, Virtanen I. Antibodies to cytoplasmic intermediate filaments in rheumatic diseases. 7 Rheumatol 1983; 10:

4 Senecal J L, Oliver J, Rothfield N. Anticytoskeletal autoantibodies in the connective tissue diseases. Arthritis Rheum connective tissue

5 Dasgupta B, Duke O, Kyle V, Macfarlane D G, Hazleman B L, Panayi G S. Antibodies to intermediate filaments in polymyalgia rheumatica and giant cell arteritis: a sequential study. Ann Rheum Dis 1987; 46: 746-9.

6 Espinoza L R, Jara L, Silveira L H, et al. Anticardiolipin antibodies in Polymyalgia rheumatica-giant cell arteritis: association with severe vascular complications. $\mathrm{Am} \mathcal{F} \mathrm{Med}$ 1991; 90: 474-8.

7 Dasgupta B, Panayi G S. Interluekin-6 in serum of patients with polymyalgia rheumatica and of patients with polymyalgia rheumatica and giant cell
$456-8$.

8 Armstrong R D, Behn A R, Panayi G S, Welsh $\mathrm{K}$ I. Histocompatibility antigens in polymyalgia rheumatica and giant cell arteritis. F Rheumatol 1983; 10: 654-61.

9 Dasgupta B, Duke O, Timms A M, Pitzalis C, Panayi G S. Selective depletion and activation of CD8 + lymphocytes from peripheral blood of patients with polymyalgia rheumatica and of patients with polymyalgia rheumatica and giant cell ar

10 Blaschek M A, Boehme M, Jouquan J, et al. Relation of antivimentin antibodies to anticardiolipin antibodies in systemic lupus erythematosus. Ann Rheum Dis 1988; 47 708-16

Prevalence of antibodies to intermediate filaments (AIF) in PMR patients (22) at different stages of the disease and in normal controls (31). Stage in disease: 1) Before treatment; 2) $5 \cdot 6$ months after initiation of treatment; 3) 11.8 months after treatment; 4) Off all treatment (25.6 months after onset of disease). 